\title{
Benefits of a Project Finance Approach to Infrastructure Development in Ghana: The Need to Adopt a Public Private Partnership Model
}

\author{
Karikari Amoa-Gyarteng ${ }^{1}$ \\ ${ }^{1}$ School of Business Administration, Ghana Baptist University College, Ghana \\ Correspondence: Karikari Amoa-Gyarteng, Dean of Students, School of Business Administration, Ghana Baptist \\ University College, Ghana. E-mail: kariamoa1@gmail.com
}

Received: January 16, 2015

Accepted: February 5, $2015 \quad$ Online Published: February 10, 2015

doi:10.5430/rwe.v6n1p151

URL: http://dx.doi.org/10.5430/rwe.v6n1p151

\begin{abstract}
This article sheds light on the extent to which private entities partake in the provision of transport infrastructure to the Ghanaian public. The paper compares Public-Private Partnership(PPP) arrangements between Ghana and the rest of the world including Sub-Saharan Africa and concludes that PPP is not been extensively utilized. There are benefits in falling on PPP arrangements to provide infrastructure. The non-recourse nature of project finance is well acclaimed. The use of PPP also frees up public funds for other equally important projects. Not downplaying the drawbacks of Public-Private Partnerships, this paper urges the Ghanaian government to launch a PPP initiative on road infrastructure especially in the face of limited public sector resources.
\end{abstract}

Keywords: project finance, public private partnership, non-recourse, transport, infrastructure, Ghana

\section{Introduction}

Governments all over the world push to satisfy a social contract with its citizens by providing infrastructure. However, many times (especially in developing countries) this quest is to no avail. There is always pressure on government treasury. The need to provide roads is held in check by an equally pressing need for good healthcare facilities, good schools inter alia.

According to KPMG (2014), economic powerhouses have historically used public money or debt security to fund developments. As recommended in the KPMG report, the private sector should play a considerable part in financing infrastructure as government finance alone is proving inadequate. McTernan \&Valen (2014) report that the Ghana government is required to spend an average of $\$ 1.2$ billion a year from 2014 to 2024 to fill infrastructure gaps.

The government clearly is failing in this pursuit. In 2010, the National Development Planning Commission (NDPC) reported that out of $66,220 \mathrm{~km}$ road network, only $41 \%$ was in good condition. A huge factor which is indicative of how the government is struggling to provide good transportation infrastructure is the duration or time it takes to complete a road project. As reported by McTernan \&Valen (2014), the Kpando-Worawora-Dambai highway for example, which is $70 \mathrm{~km}$, is still under construction ten years after it was launched.

\subsection{State and Potential Source of Distress of Infrastructure Projects in Ghana}

A disconcerting reality in Ghana is that there is a widespread financing gap between infrastructure provision and funding. Central government coffers have many times turned out to be inadequate in financing huge projects (Ngowi et al., 2006). The stress emanating from the inadequacy of funds creates delays in project delivery (Frimpong et al., 2003). This is typified by the Achimota-Ofankor road project which by all accounts is one of Ghana's important road infrastructure projects.

According to the Auditor General (2013), the Achimota-Ofankor road project was started in November 2006. It is a $5.7 \mathrm{~km}$ stretch and it forms part of the Kumasi-Accra highway which joins the two biggest cities in Ghana. Traffic is in the region of 15,000 vehicles per day. The government embarked on the project at an estimated cost of GHC 40.4million. Project completion date was scheduled for November 2009.

However, as stated in the 2013 report of the Auditor General, as of December 2011, two clear years after the project completion date, the project was just about $88 \%$ complete and the estimated cost had ballooned to GHC 128 million. Prolonged construction activities served as a stressor for commuters. A publicly funded project, the Auditor General 
(2013) reports that in 2007 no payment was issued. Moreover, budget allocations for the project were less compared to yearly invoiced interim power certificates (IPC). This is depicted in appendix 1.

Exacerbating the financial issues were also issues of contractor selection not meeting requirements of Ghana's public procurement act. Unfortunately, the scenario as described above cuts across various state funded road infrastructure projects. The afore-stated distress factors can adequately be eliminated if the government developed a PPP model that will enable private entities to finance, construct, manage (and eventually transfer back to state ownership) important and huge road projects.

\subsection{Alternative Funding Sources of Infrastructure Development}

As contained in the National Treasury/PPP Manual (2001), infrastructure can be financed through one of the following ways:

1. Public Finance: In this kind of arrangement, the government funds the project through its own equity or through borrowed funds.

2. Corporate Finance: This is the kind of financing in which a private company borrows funds to construct a project which is very likely not too capital intensive. It repays borrowed money from operating income.

3. Project Finance: Project finance involves a consortium of firms that establish a special purpose vehicle (SPV) to build a large project which most than likely, is very capital intensive. Funding is from equity contributions from each sponsor and funds from lenders. Sponsors can also choose to become lenders.

\section{Literature Review}

Gatti (2008) defines project finance as the kind of financing that does not require creditworthiness of the sponsor but on the project's ability to repay the debt. In the words of Gardner and Wright (2014), project finance is the raising of finance on a limited recourse basis in order to develop a huge infrastructure through a special purpose vehicle that happens to be the borrower and which will have to generate sustainable cash flows to repay debts.

As reported in the National Treasury/PPP Manual (2001), project finance limits the risk of stakeholders by distributing risk across parties that are in better positions to mitigate them. The National Treasury/PPP Manual (2001) further explains that in project finance, an independent special purpose vehicle is put in place to raise needed funds which are repaid from revenues and assets of the project. Project finance enables projects to be built by private financing and this has the potential of scaling back global government financing of infrastructure (Fight, 2006).

\subsection{History of Project Financing}

According to Gardner and Wright (2014), project finance emanated from Greek and Roman merchants who employed the technique as a risk mitigating measure in their marine trading. Loans were advanced based on the understanding that it will be repaid solely from the proceeds of the sale of cargo on the voyage which is akin to the project finance arrangement of using internally generated cash flows to settle debts and make dividend payments.

Gardner and Wright (2014) report that the technique was widely accepted in the 1970's and used extensively in the development of major projects such as the North Sea Oil fields. The United Kingdom, in the estimation of Gardner and Wright (2014) is the most prolific user of the project finance technique and it has a Private Finance Initiative (PFI) in place. The UK PFI is an adaptation of the more generic public private partnership concept.

\subsection{Overview of the Public Private Partnership (PPP) Model}

The Japan External Trade Organization-JETRO report (2010) which centers on private sector participation, defines PPP as a concept or model which brings public and private participants to operate in unison with the common goal of providing infrastructure. It is a cross between full privatization and state ownership of infrastructure (JETRO, 2000). As is commonly the case, the end result is the provision of infrastructure for the benefit of a public sector client (JETRO, 2000).

As posited by Debande (1999), the contractual regime that mostly defines the public authority-private investor relationship is the "Concession" arrangement. Debande (1999) suggests that when the contract is in operation, the private investor, in this instance the project company, charges tolls and fees to generate cash flows big enough to compensate for the debt and equity used to build the project.

\subsection{Types of Public Private Partnership Arrangements}

The World Bank (2004) classifies contract structures under four categories: 
Concessions: Under this arrangement, a private investor assumes control of the management of a publicly owned road for a stated period. It also assumes investment risk. The World Bank (2004) further classifies "Concessions" into
a. Rehabilitate-Operate-Transfer (ROT)
b. Rehabilitate-Lease-Transfer (RLT)
c. Build-Operate-Transfer (BROT)

Greenfield Projects: This is an arrangement under which a private equity, wholly or in conjunction with the state, constitutes a special purpose vehicle which builds and operates a new road for a period as specified in the contract. At the end of the period, the road becomes fully state owned. A further classification of Greenfield projects as given by the World Bank (2004) includes:
a) Build-Lease-Own (BLO)
b) Build-Own-Operate-Transfer (BOOT)
c) Build-Own-Operate (BOO)

Management and Lease Contracts: This is the type of contract in which a private firm is given management of a state-owned stretch of road for a given period of time. The private firm does not own the infrastructure and it does not make investment and financial decisions.

Divestitures: In this instance, the private entity purchases a stake in a toll road that has been offered on a privatization program or in a public offering.

\section{Public Private Partnership Initiatives across the World and Their Benefits}

According to Ribero and Dantas (2006), inadequate public sector resources for infrastructure financing have resulted in private investment led infrastructure schemes across the world. The World Bank (2002) reports that between 1990 and 2001, six hundred and sixty two (662) transport projects with $\$ 135$ billion private participation were ongoing.

Table 1 is an adaptation from the World Bank (2002) and it is a tabular representation of PPP led transport projects worldwide.

Table 1. Transportation PPP projects worldwide between 1990 and 2001

\begin{tabular}{llll}
\hline Country & $\begin{array}{l}\text { Total Length Of Toll } \\
\text { Roads In Operation } \\
(\text { Km) }\end{array}$ & $\begin{array}{l}\text { Autos Per } \\
1,000 \text { Pop }\end{array}$ & $\begin{array}{l}\text { Extent of Private } \\
\text { Sector Involvement }\end{array}$ \\
\hline Argentina & 197 & $1997)$ & \\
\hline Brazil & 856 & 67 & Moderate \\
\hline Chile & 3 & 109 & High \\
\hline China & 4735 & 8 & Moderate \\
\hline Colombia & 1330 & 38 & High \\
\hline France & 6716 & 521 & High \\
\hline Hong Kong & 68 & 74 & High \\
\hline Hungary & 254 & 272 & High \\
\hline Indonesia & 472 & 21 & Moderate \\
\hline Italy & 6440 & 679 & High \\
\hline Malaysia & 1127 & 152 & High \\
\hline Mexico & 6061 & 133 & High \\
\hline Philippines & 168 & 12 & High \\
\hline Spain & 2255 & 457 & High \\
\hline Thailand & 91 & 105 & High \\
\hline United Kingdom & 8 & 406 & Moderate \\
\hline United States & 7363 & 760 & High \\
\hline World Bank & & & Low \\
\hline
\end{tabular}

Source: World Bank (2002) 
The extent of private participation was low, moderate or high for different countries. Out of the 17 countries that were captured in the World Bank (2002) report, the extent of private sector involvement in infrastructure development in 12 countries was high. This signifies that there are benefits that these nations are deriving from allowing the private sector to lead the way in building infrastructure projects. Some of the benefits are set out by JETRO (2010) and they include:

- A general reduction in operating cost as it is compensated by synergies from combining design, construction and operation. In PPP projects, there is transfer of risk to the private sector and moreover, time table slippages for project completion are generally mitigated.

- Encouragement of innovation and efficiency which enhance the quality of infrastructure. In a PPP project, new facilities are provided efficiently because the project company will only receive payment when the facility is available for use.

- A harnessing of the expertise, innovation and experience of the private sector by the public sector who can utilize the newly acquired for future developments.

\subsection{Drawbacks in PPP Schemes}

According to Tanaka et al. (2005), between 1991 to 2003, 31 out of 359 toll road projects were cancelled across the world and taken over by the state. This ascertains that there are inherent risk and uncertainty in PPP projects. Like all other project financing transactions, risk in PPP road schemes should be assigned to the participant that is best placed to mitigate it.

The National Treasury/PPP Manual (2001) lists several risks including financial risk. They span the risk of incurring an increase in interest expense owning out of completion risk to political risk coming out of unstable political and legal regimes. The inability to complete a project on time may emanate from bad weather (force majeure risk), late delivery of equipments or labor strikes. There is also the possibility of residual value risk. These risks if not properly managed can lead to pecuniary distress which will require restructuring.

\subsection{How to Eliminate Distress Factors in a PPP Arrangement}

Distress factors in a PPP arrangement as with all other project finance arrangements, can be traced largely to cash flow issues. According to Castle (1975), cash flow issues account for $71 \%$ of all distresses in project finance. Schaufelberger (2003) posits that to reduce financial risk in PPP arrangements, project sponsors should select projects that give longer concession periods and higher government involvement. This gives flexibility in financing.

In the Castle (1975) study that involved seventeen projects, there were completion delays in $59 \%$ of the projects under consideration. Delays in completion could be held in check if the parties that provide engineering and construction are liable to post a bond that will be drawn in the event of certain eventualities such as project delays (National Treasury/PPP Manual, 2001).

Political risk that opens the project to expropriation and other risks could be minimized by the use of insurance likewise force majeure risk. The risk of low demand for the service provided by the project is another predicator of financial distress. Project sponsors reduce its possibility by requesting governments to include automatic rate increases, exclusive rights to monopolize the service among other things in the concession agreement (National Treasury/PPP Manual, 2001).

\section{Analysis of Extent of Private Sector Involvement in Infrastructure Development in Ghana}

The extent to which public private partnerships have been adopted as an infrastructure development measure in Ghana was analyzed with data from the World Bank spanning 2000 to 2013. Data on Ghana and that of major regions across the world were extracted. A comparison was then made between PPP figures from Ghana and other regions of the world including Sub-Saharan Africa. 
Table 2. Cumulative investment in projects by region (US\$ million)

\begin{tabular}{lllllll}
\hline $\begin{array}{l}\text { Year of } \\
\text { Investment }\end{array}$ & $\begin{array}{l}\text { East Asia \& } \\
\text { Pacific }\end{array}$ & $\begin{array}{l}\text { Latin America \& } \\
\text { Caribbean }\end{array}$ & $\begin{array}{l}\text { Europe \& Central } \\
\text { Asia }\end{array}$ & South Asia & $\begin{array}{l}\text { Sub Saharan } \\
\text { Africa }\end{array}$ & $\begin{array}{l}\text { Total } \\
\text { Investment }\end{array}$ \\
\hline 2000 & $1,587.00$ & $1,708.00$ & - & 96.00 & 17 & $3,408.00$ \\
\hline 2001 & $1,346.00$ & $2,766.00$ & - & 131.00 & 0 & $4,243.00$ \\
\hline 2002 & 346.00 & $1,446.00$ & - & 426.00 & 0 & $2,218.00$ \\
\hline 2003 & $3,356.00$ & 224.00 & - & 516.00 & 17 & $4,113.00$ \\
\hline 2004 & 467.00 & $1,146.00$ & - & 921.00 & 0 & 2534.00 \\
\hline 2005 & $3,386.00$ & $2,131.00$ & - & 254.00 & 0 & $5,771.00$ \\
\hline 2006 & $2,862.00$ & $1,847.00$ & - & $5,023.00$ & 0 & $9,732.00$ \\
\hline 2007 & $2,849.00$ & $8,085.00$ & - & $3,150.00$ & 0 & $14,084.00$ \\
\hline 2008 & 732.00 & $9,077.00$ & - & $4,467.00$ & 382 & $14,658.00$ \\
\hline 2009 & $1,362.00$ & $9,686.00$ & - & $2,853.00$ & 264 & $14,165.00$ \\
\hline 2010 & - & $4,469.00$ & $2,818.00$ & $13,233.00$ & 0 & $20,520.00$ \\
\hline 2011 & $1,104.00$ & $4,787.00$ & - & $11,695.00$ & 97 & $17,683.00$ \\
\hline 2012 & $1,989.00$ & $2,727.00$ & $5,138.00$ & $20,084.00$ & 0 & $29,938.00$ \\
\hline 2013 & 702.00 & $9,225.00$ & - & $1,739.00$ & 0 & $11,666.00$ \\
\hline Grand Total & $22,088.00$ & $59,324.00$ & $7,956.00$ & $64,588.00$ & 777 & $154,733.00$ \\
\hline
\end{tabular}

Source: World Bank (2014)

Table 3. Total PPP investment in Ghana (US\$ million)

\begin{tabular}{llllll}
\hline Year of Investment & Energy & Telecom & Transport & Water and Sewage & Total \\
\hline 2000 & 0 & 0 & 10 & 0 & 10 \\
\hline 2001 & 0 & 12 & 0 & 0 & 12 \\
\hline 2002 & 0 & 12 & 0 & 0 & 12 \\
\hline 2003 & 0 & 0 & 0 & 0 & 0 \\
\hline 2004 & 0 & 81 & 0 & 0 & 81 \\
\hline 2005 & 590 & 52 & 0 & 0 & 642 \\
\hline 2006 & 0 & 215 & 0 & 0 & 215 \\
\hline 2007 & 300 & 420 & 0 & 0 & 720 \\
\hline 2008 & 0 & 1,434 & 0 & 0 & 1434 \\
\hline 2009 & 140 & 847 & 0 & 0 & 987 \\
\hline 2010 & 0 & 290 & 0 & 0 & 666 \\
\hline 2011 & 360 & 306 & 0 & 0 & 793 \\
\hline 2012 & 440 & 227 & 0 & 126 & 638 \\
\hline 2013 & 440 & 198 & 0 & 0 & 6500 \\
\hline Grand Total & 2270 & 4094 & 10 & 126 & \\
\hline
\end{tabular}

Source: World Bank (2014) 


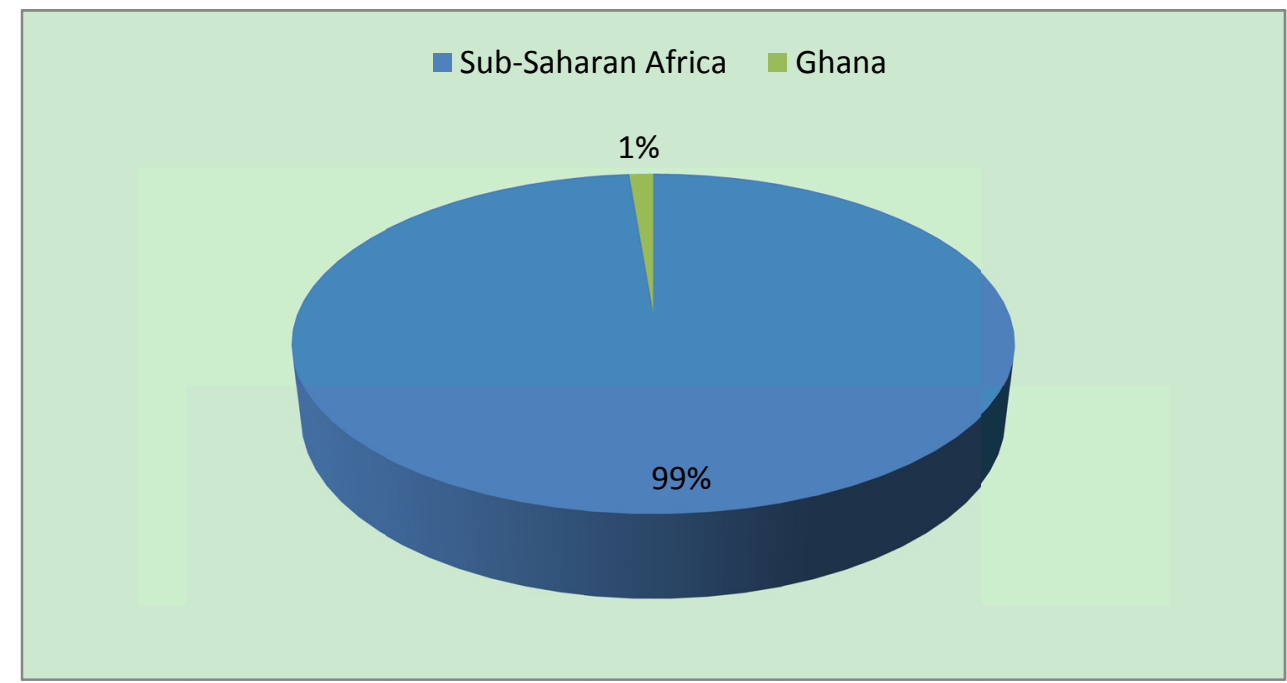

Chart 1. Extent of PPP in Ghana compared to rest of Sub-Saharan Africa

PPP investment in the transport sector in Ghana from 2000 to 2013 was just $1 \%$ of the total PPP investments in Sub-Saharan Africa.

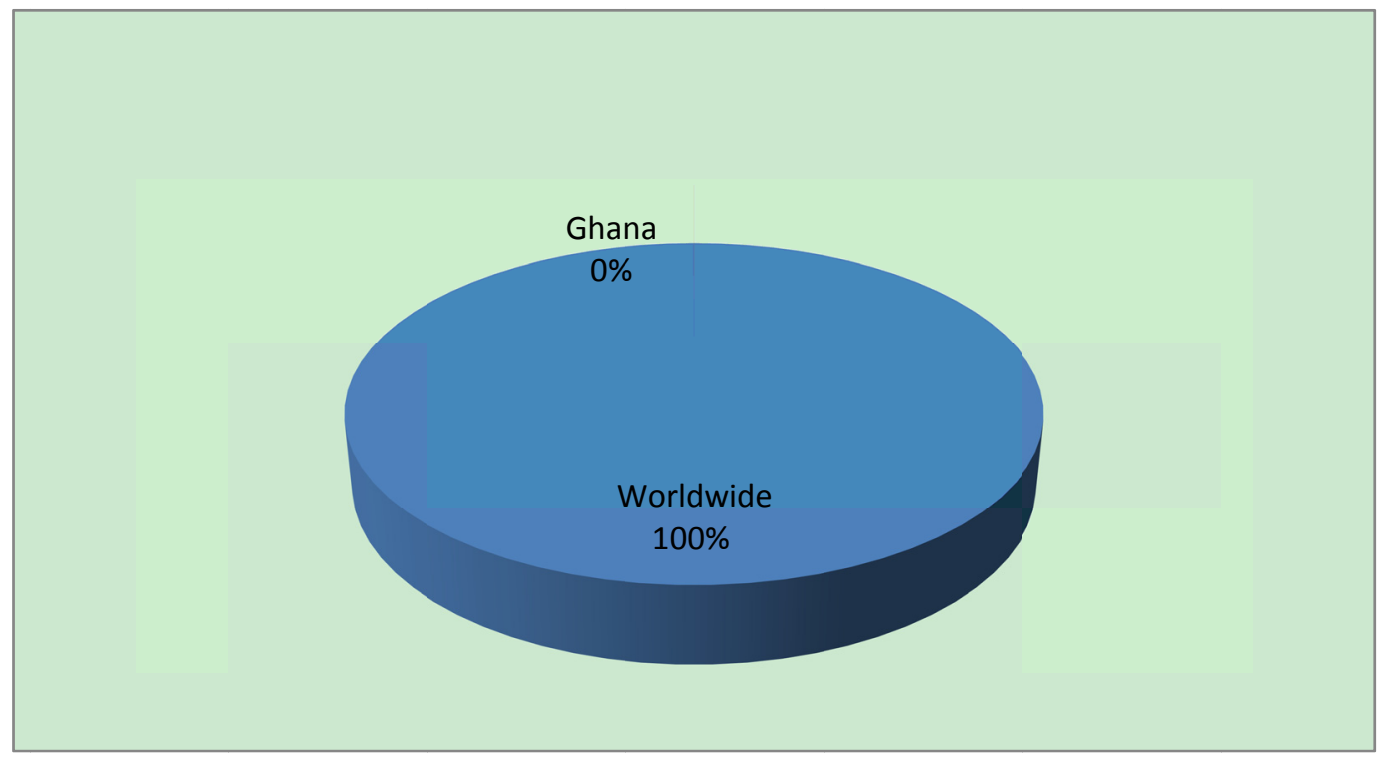

Chart 2. Extent of PPP use in Ghana compared to total worldwide PPP investments

Compared to worldwide PPP investments, private led transport infrastructure projects in Ghana was negligible in the years under consideration.

\section{Discussion and Conclusion}

Figures from table 1 show that total investments in public-private partnerships arrangements across Sub-Saharan Africa was US $\$ 777$ million between 2000 and 2013. This figure was the lowest compared to the other regions of the world. South Asia enjoys the highest private funding led infrastructure projects.

The region, in the account of Nataraj (2007), is a quarter of the world's population and represents one of the fastest growth rates in the world. Infrastructure needs therefore are enormous and this may account for the high PPP led infrastructure development. The fact that the South Asia region has $40 \%$ of the world's poor (Nataraj, 2007) suggests that governments in the region have competing interest for funds and therefore cannot afford to single handedly provide funding for infrastructure projects. 
Sub-Saharan Africa has similar geo-economic indicators as South Asia and must follow their lead in the direction of utilizing PPP arrangements to develop a reliable transportation network. Even though PPP investments in transport in Sub-Saharan Africa are generally small, Ghana makes up only a paltry $1 \%$ of its total investments. This epitomizes the low extent to which PPP as a model is utilized in the transport sector in Ghana. In the Energy and Telecom sectors of Ghana however, public private partnership investments are significant. This goes to show that the PPP framework is in place and it should be harnessed to boost the provision of transport infrastructure.

\section{References}

Auditor General. (2013). Performance Audit Report of the Auditor General on the Construction of Achimota-Ofankor Road Project. Auditor General's Department. Accra, Ghana.

Castle, G.R. (1975). Project Financing-Guidelines for the Commercial Banker. Journal of Commercial Banking, 57, 14-30.

Debande, O. (1999). Private Financing of Infrastructure. An Application to Public Transport Infrastructure. Retrieved $4^{\text {th }}$ January 2015, from http://prijipati.library.usyd.edu.au/bitstream/2123/6532/1/thredbo6-theme2-Debande.pdf

Fisher, G., \& Babbar, S. (1996). Private Financing of Toll Roads. RMC Discussion Paper Series 117. Retrieved $30^{\text {th }}$ December 2014, from http://www.worldbank.org/transport/roads/tr-docs/117.pdf

Frimpong, Y., Oluwoye, J., \& Crawford, L. (2003). Causes of Delay and Cost Overruns in Construction of Ground Water Projects in Developing Countries: Ghana as a Case Study. International Journal of Project Management, 21(1), 321-326. http://dx.doi.org/10.1016/S0263-7863(02)00055-8

Garnder, D., \& Wright, J. (2014). Project Finance. Retrieved $1^{\text {st }}$ January 2015, from http://www.hsbcnet.com/gbm/attachments/products-services/financing/project-finance.pdf

KPMG. (2014). Infrastructure 100 World Markets Report. Retrieved $5^{\text {th }}$ January 2014, from http://www.kpmg.com/global/en/issuesandinsights/articlespublications/infra100-world-markets/pages/infrastruc ture-100-world-markets-report.aspx

McTernan, B.A., \& Valen, V.M. (2014, January 20). Ghana's Funding Gaps "Go-Slows" and Chinese Hopes. The African Report. Retrieved December $30^{\text {th }} 2014$, from http://www.theafricareport.com

Nataraj, G. (2007). Infrastructure Challenges in South Asia: The Role of Public-Private Partnerships. Retrieved $10^{\text {th }}$ January 2015, from http://www.adbi.org/files/dpso.infrastructure.challenges.south.asia.pdf

National Treasury/PPP Manual. (2001). Project Finance. Introductory Manual on Project Finance for Managers of PPP Projects. Retrieved $5^{\text {th }}$ January 2015, from http://www.observatory.gr/files/meletes/PFI_Manual.pdf

Ngowi, A.B., Pienaar, E., Akindele, O., \& Iwisi, D. (2006). Globalization of the Construction Industry: A Review of Infrastructure Financing. Journal of Financial Management of Property and Finance, 11(1), 45-48.

Ribero, K., \& Dantas, A. (2006). Public-Private Partnership Initiatives Around the World: Learning From the $\begin{array}{lllll}\text { Experience. } & \text { Retrieved } & 4^{\text {th }} & \text { January } & 2015,\end{array}$ http://ir.canterbury.ac.nz/bitstream/10092/211/2/12604296_Main.pdf.txt

Schaufelberger, J.E. (2003). Alternate Financing Strategies for Build-Operate-Transfer Projects. Journal of $\begin{array}{llll}\text { Construction Engineering } & \text { 205-213. }\end{array}$ http://dx.doi.org/10.1061/(ASCE)0733-9364(2003)129:2(205)

Tanaka, F.D., Tsutsumi, M., Ishida, H., \& Okamoto, N. (2005). Private Finance for Road Projects in Developing Countries: Improving Transparency through Risk Assessment. Journal of the Eastern Asia Society for Transportation Studies, 6, 3899-3914.

World Bank. (2002). Private Participation in Infrastructure: Trends in Developing Countries in 1996-2001. World Bank, Washington, USA.

World Bank. (2014). Private Participation in Infrastructure Database. World Bank, Washington, USA. 


\section{APPENDICES}

Appendix 1

\begin{tabular}{|l|l|l|l|}
\hline Year & $\begin{array}{l}\text { Budget amount } \\
(\mathrm{GH} \phi)\end{array}$ & $\begin{array}{l}\text { Actual expenditure } \\
(\mathrm{GH} \phi)\end{array}$ \\
\cline { 2 - 4 } & $159,600.00$ & $7,187,917$ \\
\hline 2006 & $2,805,024$ & nil \\
\hline 2007 & $4,055,908$ & $13,133,220$ \\
\hline 2009 & $* * *-$ & $11,557,368$ \\
\hline & & $21,840,735$ \\
\hline 2010 & $10,448,011$ & $34,812,089$ \\
\hline & & $88,531,329$ \\
\hline
\end{tabular}

Budget and Expenditure on the Achimota- Ofankor Project from 2006 to 2011 (Auditor General, 2013)

Appendix 2

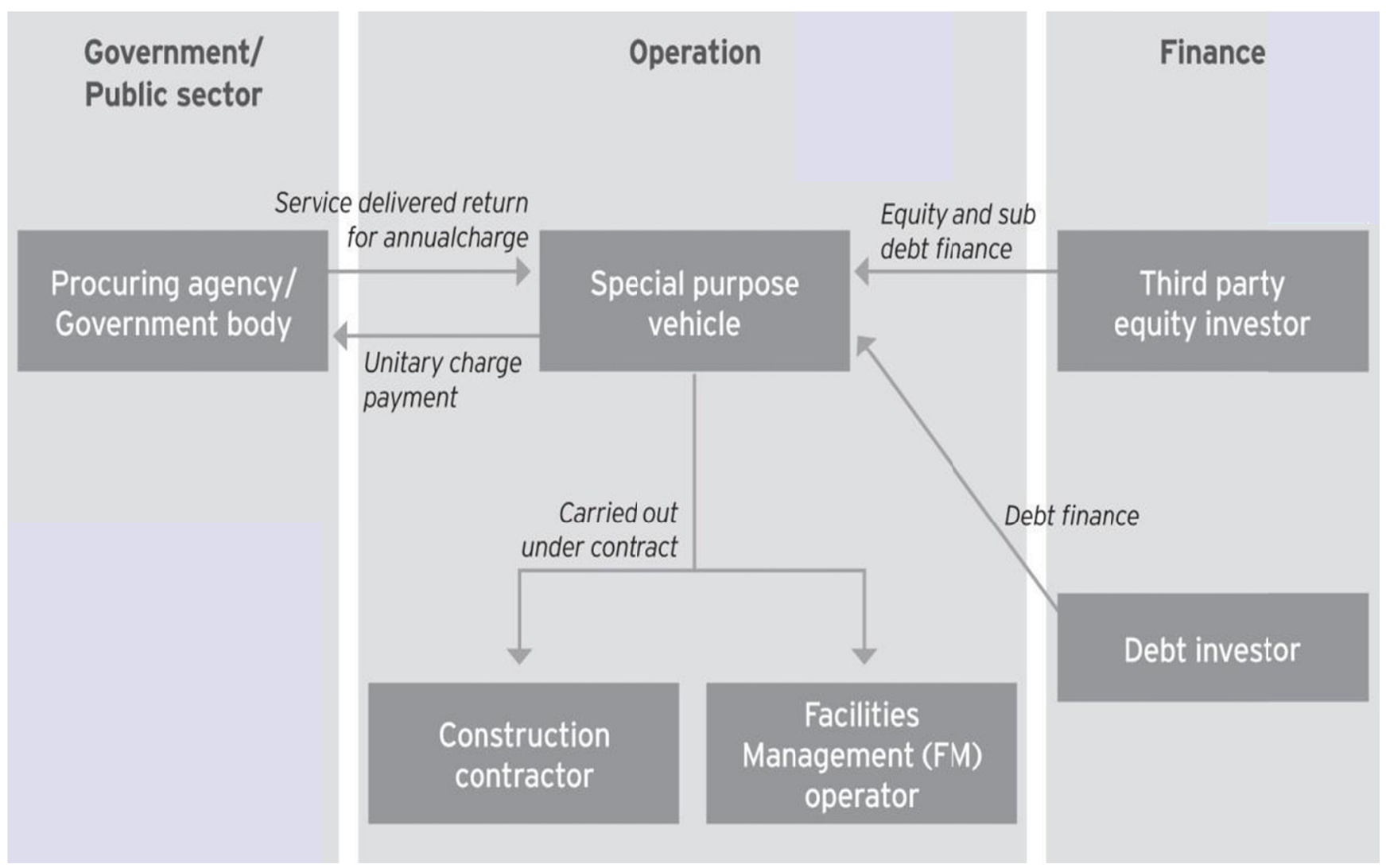

Special Purpose Vehicle Used for the Provision of Infrastructure in PPP Arrangements (JETRO, 2010) 